\title{
Internal Corporate Governance and Financial Performance Nexus; a Case of Banks of Pakistan
}

\author{
Uzma Bashir $^{1}$, Ummara Fatima ${ }^{1, ~}$, Sundas Sohail $^{1}$, Farhat Rasul ${ }^{2}$, Rabia Mehboob ${ }^{1}$ \\ ${ }^{1}$ School of Commerce \& Accountancy, Minhaj University, Lahore, Pakistan \\ ${ }^{2}$ Pakistan Institute of Development Economics, Islamabad, Pakistan
}

Email address:

ummarafatima@ymail.com (U. Fatima), ummara.sca@mul.edu.pk (U. Fatima)

${ }^{*}$ Corresponding authors

\section{To cite this article:}

Uzma Bashir, Ummara Fatima, Sundas Sohail, Farhat Rasul, Rabia Mehboob. Internal Corporate Governance and Financial Performance Nexus; a Case of Banks of Pakistan. Journal of Finance and Accounting. Vol. 6, No. 1, 2018, pp. 11-17. doi: 10.11648/j.jfa.20180601.12

Received: August 29, 2017; Accepted: December 5, 2017; Published: January 20, 2018

\begin{abstract}
The persistence of corporate governance (CG) is to expedite operative and cautious management which can transport the enduring success of the company. The performance of any firm or bank is vibrantly enhanced by corporate governance. The key contribution of this study to governance literature is that; it demonstrates how the presence of the internal governance mechanism influence the bank performance. The study makes an attempt to measure the impact of internal governance indicators (Board Structure and Ownership Structure) on the financial performance (Return on Equity, Return on Assets and Earning Per Share) of the banks of Pakistan under the presence of control variables (leverage and size). The selected sample consist of 30 banks (public, private and specialized), which are listed at Pakistan Stock Exchange (PSE) for the period 2008-2014. The study takes 30 banks listed in PSE, formerly KSE and, check how corporate governance impact on all the listed banks at PSE, irrespective of their nature of operation. Study also extended the time frame till 2014. The study comprises of three models. The regression analysis results reveal that the majority of the internal governance indicators of Model 2 and 3 show significant relationship with ROE and EPS whereas, majority of the internal governance indicators of Model 1 depict insignificant relationship with ROA. The results depict that in a developing country like Pakistan there are sound codes of corporate governance but, their proper implementation is missing.
\end{abstract}

Keywords: Corporate Governance, Board Structure, Ownership Structure, Financial Performance, PSE

\section{Introduction}

Corporate Governance (CG) is a contentious issue and, a lot of research has done in this field. The Organization for Economic Cooperation and Development (OECD) has defined CG as: "Procedures and processes according to which an organization is directed and controlled. The corporate governance structure specifies the distribution of rights and responsibilities among different participants in an organization - such as the board, managers, shareholders and other stakeholders - and lays down the rules and procedures for decision-making" [1].

In the business world, the concept of CG is substantially important. The mechanism of CG is useful for the domestic economy and, for a firm's economic growth. Corporate governance plays a vital role to enhance the financial performance of any organization including bank. As, these financial institutions are the machines for economic growth both for developed and developing countries. It is extensively recommended that the good governance leads to better performance of the bank [2]. In many past years, CG practices are changing and, are making the place of important key matter in the organizational setup. A corporate governance index has statistically and economically noteworthy relationship on market valuation [3]. Directly or indirectly corporate governance is very intensively associated to strengthen the economy of a country.

The survival of a bank depends on its financial performance. Financial performance is important for different investors of the company [4]. Researchers have measured financial 
performance through ROA, ROE, EPS, DPS, Tobin's Q, market to book ratio etc. Poor financial planning causes many business to fail accompaning the bad application of codes of governance e.g (Enron and WorldCom). Consequently, sound governance tools are important for a running or growing business to get high level of financial measure of the performance [2].

Codes of corporate governance are highly a matter of significance for developing countries including Pakistan. In Pakistan, the codes of corporate governance are introduced by Securities and Exchange Commission of Pakistan (SECP) in early March 2002, but later in 2012 it was reviewed for making some alterations [6].

The drive of this research work is to check the influence of $\mathrm{CG}$ on the financial performance of the listed banks of Pakistan. In the present scenario, most of the studies are exploring the relationship of internal CG mechanism and financial performance of the banks of Pakistan e.g., [2]. This study makes an attempt to reveal the same relationship but with extended time frame and data collection. The study selects thirty banks listed at PSE (Pakistan Stock Exchange). This research facilitates the banking firms and also to the corporate patrons and, different financiers to capitalize their financing in the banks of Pakistan.

\subsection{Objectives of Study}

The objectives of the study are as follow:

To empirically investigate the relationship between board structure and financial performance of the listed banks of Pakistan.

To examine the relationship between ownership structure and financial performance of the listed banks of Pakistan.

\subsection{Hypotheses}

The study has hypothesis as follow:

H1: Board structure and, ownership structure has a positive relationship with ROA.

$\mathrm{H} 2$ : Board structure and, ownership structure has a positive relationship with ROE.

H3: Board structure and, ownership structure has a positive relationship with EPS.

\section{Review of Literature}

The mechanism of CG varies in different countries according to their rules and regulations, even it varies from institution to institution. The effectual operations of CG in any organization enhances its financial value [2]. Previous literature worked on numerous studies checking the relationship between $\mathrm{CG}$ and performance.

The performance of an organization significantly affected by board size. With respect to increase and decrease in board size different studies have different findings. The smaller board size shows more efficiency than bigger boards, as some directors may yield individual profits on the struggle of others [7]. Board size is inversely related to the firm value
[8]. A board is less likely to function efficiently when it becomes larger [9]. [10;11] have explored that there is a negative relationship between board size and performance. On the other hand, various studies have explored a direct relationship between board size and performance. Board size has a direct significant relationship with performance of the banks $[12 ; 13 ; 14]$.

The primary role of non-executive directors is to enhance the procedures and, to decrease the agency problem. Corporate governance codes such as Sarbanes Oxley Act intensely propose and frequently obligates that a board should include a noteworthy portion of non-executive directors. Thus, for non-executive directors it is unlikely to work beside the benefit of shareholders [9]. The non-executive director's portion in the board also has an impact on performance. Share of outside directors positively impact the firm performance [15]. On the other hand, some studies have revealed an opposite association between board composition and performance. There is a negative association between outside directors and performance $[16 ; 17 ; 14]$. Annual general meeting (AGM) is a good measure of CG. AGM has negative significant relationship with CG [19]. Meanwhile, AGM has insignificant relationship with the performance [20].

Different ownership types have different impact on performance. Ownership types may include; "family ownership, managerial ownership, institutional ownership, state ownership, foreign ownership" etc. Corporate governance and ownership structure have vital implications on the financing decisions of the firms [21]. Agency issues amongst shareholders and managers aggravate the managers to exercise fewer effort to control the firm. Furthermore, these concerns may provoke the managers to use assets for their private use. In order to attain the attention of the managers and, stockholders by limiting them not to discard the firm's assets for their personal use, a rise in the shares retained by the managers may help. Several studies on CG have used managerial ownership and, explored the impact on performance, though, their results are mixed. [22] explored that the firms with no managerial ownership perform less efficiently, in comparison to the firms with large managerial ownership; thus, it has a progressive relationship with bank's financial performance [23]. Meanwhile, managerial shareholding has negative significant relationship with debt to equity ratio $[21 ; 14]$.

The ownership held by big financial organizations, pension funds or endowments is called as institutional ownership. In Pakistan institutional ownership do not have a positive observing role [24]. While on the other hand, some studies have explored that the percentage of both institutional stock ownership and institutional stockholders have noteworthy association with firm's operating cash flow returns [25]. Institutional ownership has a positive significant relationship with ROE and EPS [2]

Control variables effects the relationship between independent and and dependent variables. Same as, leverage and size effect the relationship between $\mathrm{CG}$ and performance. They are used to study the firm performance [3]. In the 
presence of some control variables i.e. leverage and audit firm size, a positive association occur between CG and audit fee [26]. Leverage has a significant positive relationship with financial performance [27]. On the other hand, [2] have investigated that the leverage is inversely related with the financial performance. The literature proves positive relationship amongst firm size and financial performance [2]

Unfortunately, there is lack of proper implementation of the codes of corporate governance in Pakistan. $[2 ; 28 ; 29 ; 30]$ have examined the effect of CG on performance but, they have inconsistent results. So, there is requirement to work more in this field. This study is imperative to do in a scenario of inconsistency and, to ascertain the matters that influence the performance of the banks by using sound codes of CG practices in Pakistan. The most recent work on CG in Pakistan is exploreby by [2]. This study has the privilege to add more to their work. The study take 30 banks listed in KSE now PSE and, check how corporate governance impact on all the listed banks at PSE, irrespective of their nature of operation. Study also extended the time frame till 2014.

\section{Method}

\subsection{Source of Data}

The data of corporate governance and financial performance of the selected banks is composed from the annual reports, official websites of the sampled banks and PSE from the period 2008-2014.

\subsection{Sample Size}

Thirty banks (public, private and specialized [31], listed at PSE by excluding the foreign and Islamic banks from the period 2008-2014 are taken as sample of the study. The study sample is selected through total sampling technique. The banks are selected through total population sampling, which is a type of purposive sampling technique.

The explanation of the variables used in the study are as follow:

Table 1. Operational Description of Variables.

\begin{tabular}{|c|c|c|c|}
\hline Definition of Variables & Representation & Definition & Author Contribution \\
\hline Return on assets & $\mathrm{ROA}_{\mathrm{it}}$ & "Ratio of profit before taxes to total assets" & [2] \\
\hline Return on equity & $\mathrm{ROE}_{\mathrm{it}}$ & "Ratio of profit before taxes to stockholders equity" & [2] \\
\hline Earnings per share & $\mathrm{EPS}_{\mathrm{it}}$ & "Ratio of profit before taxes to total outstanding common stocks" & [2] \\
\hline Board size & BODSIZE $_{\text {it }}$ & "Total number of board of directors" & [32] \\
\hline Out-ratio & OUTRATIO $_{\text {it }}$ & $\begin{array}{l}\text { "Ratio of non-executive directors and independent directors to total } \\
\text { number of directors" }\end{array}$ & [15] \\
\hline Annual general meeting & $\mathrm{AGM}_{\mathrm{it}}$ & "Number of general meetings in a year" & [20] \\
\hline Managerial Ownership & $\mathrm{MO}_{\text {it }}$ & $\begin{array}{l}\text { "Ratio of shares owned by the directors to total outstanding common } \\
\text { stocks" }\end{array}$ & {$[33 ; 21]$} \\
\hline Institutional Ownership & INSTOWN $_{\text {it }}$ & $\begin{array}{l}\text { "Ratio of shares owned by the financial institutions to total outstanding } \\
\text { common stocks" }\end{array}$ & {$[2 ; 32]$} \\
\hline Leverage & $\mathrm{LEV}_{\text {it }}$ & "Ratio of total liabilities to total assets" & [2] \\
\hline Bank size & LNSIZE $_{\text {it }}$ & "Natural logarithm of total assets" & [2] \\
\hline
\end{tabular}

\subsection{Methodology}

Pearson's Correlation matrix and Regression models are used to test the relationship of corporate governance and financial performance of the banking sector of Pakistan. The panel data estimation (fixed or random effect) is done by using E-Views software.

\subsection{Models for Research}

To testify the above mentioned hypothesis three models are structured which are as follow:

Model \# 1

$$
R O A_{i t}=\alpha+\beta_{1} \text { BODSIZE }_{i t}+\beta_{3} \text { AGM }_{i t}+\beta_{4} \text { OUTRATIO }_{i t}+\beta_{2} I_{N S T O W N}+\beta_{5} \text { MO }_{i t}+\beta_{6} L_{E V} V_{i t}+\beta_{7} L_{N S I Z E_{i t}}+\varepsilon_{i t}
$$

Model \# 2

$$
R O E_{i t}=\alpha+\beta_{1} \text { BODSIZE }_{i t}+\beta_{3} \text { AGM }_{i t}+\beta_{4} \text { OUTRATIO }_{i t}+\beta_{2} I N S T O W N_{i t}+\beta_{5} M O_{i t}+\beta_{6} L E V_{i t}+\beta_{7} L N S I Z E_{i t}+\varepsilon_{i t}
$$

Model \# 3

$$
E P S_{i t}=\alpha+\beta_{1} \text { BODSIZE }_{i t}+\beta_{3} \text { AGM }_{i t}+\beta_{4} \text { OUTRATIO }_{i t}+\beta_{2} \text { INSTOWN }_{i t}+\beta_{5} \text { MO }_{i t}+\beta_{6} \text { LEV }_{i t}+\beta_{7} L N S I Z E_{i t}+\varepsilon_{i t}
$$




\subsection{Conceptual Framework}

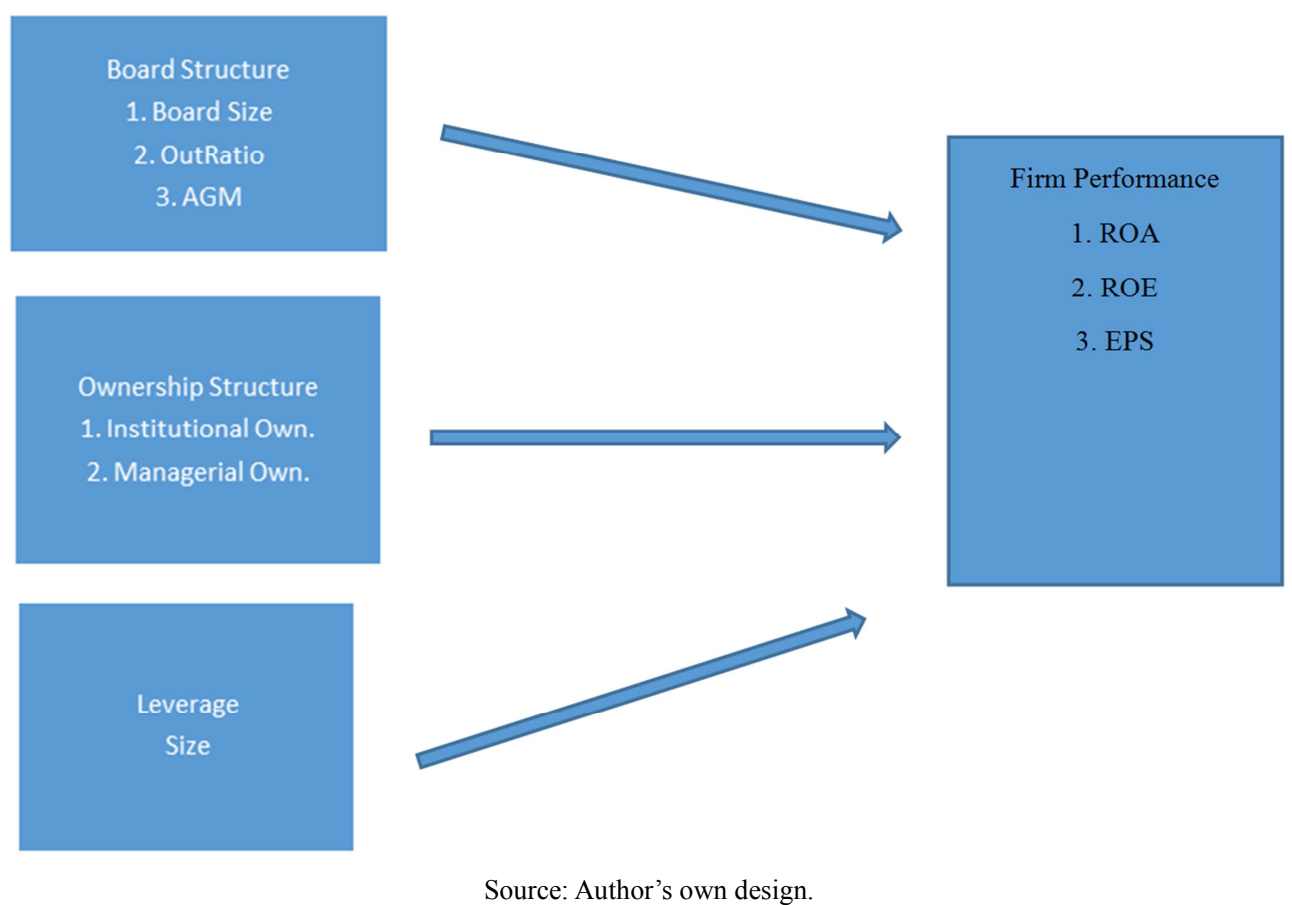

Figure 1. The conceptual frame of the relationship between corporate governance and performance.

\section{Analysis, Results and Discussions}

Empirical Results

\subsection{Multicollinearity Test}

Table 2. Pearson Correlation Matrix.

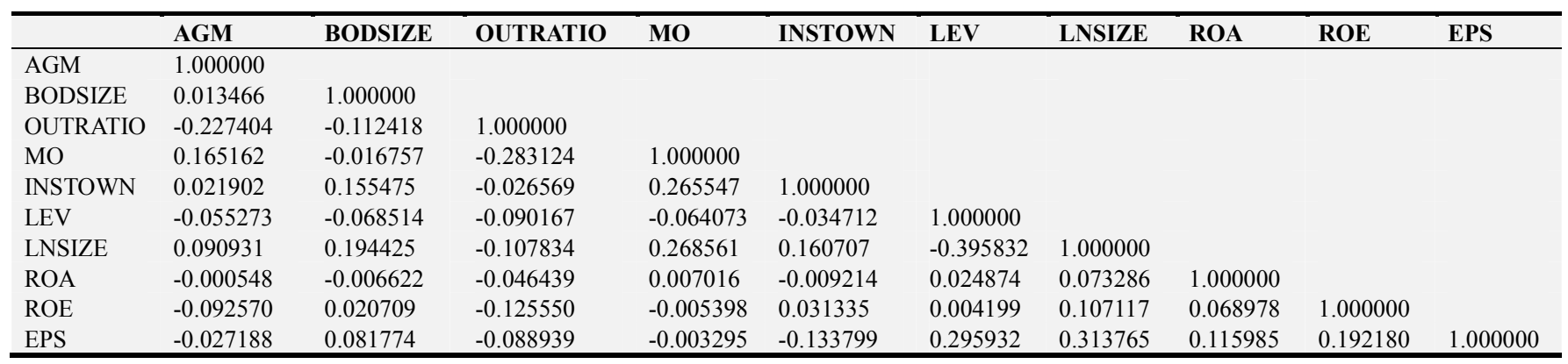

Source: Author's own calculations.

Table 2 represents the correlation analysis. This is done to check the issue of multicollinearity between variables. AGM has significant positive relationship with BODSIZE, INSTOWN, LNSIZE and negative significant relationship with LEV, ROA, ROE, and EPS. AGM has insignificant relationship with OUTRATIO and MO. BODSIZE has negative significant relationship with $\mathrm{MO}, \mathrm{LEV}, \mathrm{ROA}$ and significant positive relationship with ROE and EPS. BODSIZE has insignificant relationship with OURTRATIO, INSTOWN, and LNSIZE. OUTRATIO has negative significant relationship with INSTOWN, LEV, ROA, and EPS; and is having insignificant relationship with MO, LNSIZE, and ROE. MO is negatively significantly correlated with LEV,
ROE, and EPS; and significantly correlated with ROA. MO has insignificant relationship with INSTOWN and LNSIZE. INSTOWN has negative significant relationship with LEV, ROA and EPS. INSTOWN is positively significantly correlated with ROE and insignificant relationship with LNSIZE. LEV is positively and significantly associated with ROA and ROE; insignificant relationship with LNSIZE and EPS. LNSIZE is significantly correlated with ROA and insignificantly with ROE and EPS. ROA has significant relationship with ROE and insignificant with EPS. EPS has insignificant relationship with ROE. The results of the study are mixed showing positive and negative relationship between variables of the study. 
The results depicts that there is no issue of multicollinearity the range of (-1 to 1$)$. between variables as the correlation coefficient values are in

\subsection{Regression Results}

Table 3. Impact of Internal Governance on Bank's Performance.

\begin{tabular}{|c|c|c|c|c|c|c|}
\hline \multirow{2}{*}{ Variables } & \multicolumn{2}{|l|}{ Model 1 ROA } & \multicolumn{2}{|c|}{ Model 2 ROE } & \multicolumn{2}{|l|}{ Model 3 EPS } \\
\hline & Coefficient & Prob. & Coefficient & Prob. & Coefficient & Prob. \\
\hline $\mathrm{C}$ & $-0.256207 *$ & 0.0938 & -0.268398 & 0.6715 & $-3.748452 *$ & 0.0503 \\
\hline BODSIZE & -0.005461 & 0.5897 & -0.022049 & 0.6217 & -0.032067 & 0.2550 \\
\hline OUTRATIO & -0.082332 & 0.5336 & $-1.278125^{* *}$ & 0.0128 & $-1.215941 * * *$ & 0.0008 \\
\hline AGM & -0.001961 & 0.8017 & $-0.086342 * *$ & 0.0305 & 0.057537 & 0.1037 \\
\hline MO & -0.069558 & 0.4549 & $-0.845251 *$ & 0.0565 & $-2.520626 * *$ & 0.0277 \\
\hline LEV & $0.013861 * * *$ & 0.0000 & $0.029018^{*}$ & 0.0740 & $1.349845 * * *$ & 0.0001 \\
\hline LNSIZE & $0.019907 * * *$ & 0.0030 & $0.101605^{* * *}$ & 0.0000 & $0.420794 * * *$ & 0.0000 \\
\hline
\end{tabular}

Source: Author's own calculations.

Significance level $* \mathrm{p}<0.10, * * \mathrm{p}<0.05$ and $* * * \mathrm{p}<0.01$

Table 3 represents three models. In model 1, within the framework of random effect model, there is no significant relationship of board size, board independence, AGM, managerial ownership and institutional ownership with ROA. Leverage and size are having positive significant impact on ROA.

In model 2, within the framework of random effect model, there is no significant relationship of board size and institutional ownership with ROE but leverage (Hassan, Marimuthu, \& Johl, 2015) and size [2] are having positive significant impact on ROE. Bank assets mainly consists of deposits and more of assets means performance of the bank increases and with the increase of deposits, bank advances loan to the borrowers [2]. Managerial ownership [30], board independence $[16 ; 12 ; 14]$ and AGM are having negative significant relationship with ROE. Control variables are positively significantly related with ROE.

In model 3, within the framework of fixed effect model, there is no significant relationship of board size, annual general meeting, and institutional ownership with EPS but, leverage and size are having positive significant impact on EPS [2]. Board independence, managerial ownership are having negative significant relationship with EPS.

\section{Conclusion and Recommendations}

The previous research has explored that the board structure, ownership structure and control variables play a predominant role for a corporation to bring sound governance $[12 ; 33 ; 14 ; 8]$. In Pakistan, many previous studies mostly focused firms, but less the banking sector, that's why the board of directors, ratio of outside directors and investors of the banks may not play a predominant role for the better performance of the banks [2]. This study has explored that the role of ownership structure helps to reduce agency cost by developing good governance and to up bring the performance of the banks $(9 ; 34)$. The results depicts that the board size and institutional ownership are insignificantly related with ROA, ROE and EPS. Portion of non-executive directors and managerial ownership is insignificantly related with ROA and negatively significantly related with ROE and EPS. Annual general meeting is having insignificant relationship with ROA and EPS and negative significant relationship with ROE. Leverage and size are having significant relationship with financial performance.

Overall, the study depicts mixed results. The reason behind this is that in a developing country like Pakistan there are sound codes of corporate governance but, there is no proper implementation of these codes, even after the revision in 2011 by SBP their proper implementation is missing. There is dire need by the regulatory authorities to instruct the banks to obligate the strict application of the codes of governance in the banks of Pakistan. As suggested by [35], a well-functioning whistle blower mechanism and the control of impartial practices by ranking organizations can strengthen the application of corporate governance. For future research, external governance mechanism can be added to further discover the effects of external mechanism of corporate governance on the financial performance of the banks.

In anticipating and avoiding imminent banking crises, the study proposes vital policy suggestions, which might support academics, regulators, boards of company's managers, executives, and other market applicants. This would enhance investor's confidence for investing in bank's capital. Furthermore, the study is restricted to listed banks of Pakistan. Future research may be designed to compare the findings of this study with those that relate to non-listed private banks of Pakistan and, with the banks operating in other countries of the world. Even sectors other than banks can also be taken as sample of the study.

\section{Acknowledgements}

Authors would like to thank to Allah Almighty and, to those for whom the world has been created and to Dr. Hussain Moh-Ud-Din (Deputy Chairman BOG at MUL) for his kind support. 


\section{References}

[1] https://stats.oecd.org/glossary/detail.asp?ID=6778

[2] Sheikh, N. A., \& Karim, S. (2015). Effects of Internal Governance Indicators on Performance of Commercial Banks in Pakistan. Pakistan Journal of Social Sciences (PJSS), 35 (1), 77-90.

[3] Chong-En, B., Qiao, L., Joe, L., Frank M., S., \& Junxi, Z. (2006). An Empirical Study on Corporate Governance and Market Valuation in China. Frontiers of Economics in China, 1 (1), 83-111.

[4] Haider, N., Khan, N., \& Iqbal, N. (2015). Impact of Corporate Governance on Firm Financial Performance in Islamic Financial Institution. International Letters of Social and Humanistic Sciences, 51, 106-110.

[5] Sheikh, N. A., \& Karim, S. (2015). Effects of Internal Governance Indicators on Performance of Commercial Banks in Pakistan. Pakistan Journal of Social Sciences (PJSS), 35 (1), 77-90.

[6] https://www.secp.gov.pk/wp-content/uploads/2016/05/SECP-a mends-Code-of-Corporate-Governance.pdf

[7] Lipton, M., \& Lorsch, J. W. (1992). A modest proposal for improved corporate governance. The Business Lawyer, 59-77.

[8] Yermack, D. (2005). "Higher Market Valuation of Companies with a Small Board of Directors". $V$ Governance: An International Perspective, 1, 150-176.

[9] Jensen, M. C. (1993). The Modern Industrial Revolution, Exit, and the Failure of Internal Control Systems. The Journal of Finance, 48 (3), 831.

[10] Hassan, M., \& Halbouni, S. (2013). Corporate governance, economic turbulence and financial performance of UAE listed firms. Studies in Economics and Finance, 30 (2), 118-138.

[11] Nyamongo, E., \& Temesgen, K. (2013). The effect of governance on performance of commercial banks in Kenya: a panel study. Corporate Governance: The International Journal of Business in Society, 13 (3), 236-248.

[12] Al-Saidi, M., \& Al-Shammari, B. (2013). Board composition and bank performance in Kuwait: an empirical study. Managerial Auditing Journal, 28 (6), 472-494.

[13] Haniffa, R., \& Hudaib, M. (2006). Corporate Governance Structure and Performance of Malaysian Listed Companies. Journal of Business Finance Accounting, 33 (7-8), 10341062.

[14] Sheikh, N., Wang, Z., \& Khan, S. (2013). The impact of internal attributes of corporate governance on firm performance: Evidence from Pakistan. International Journal of Commerce and Management, 23 (1), 38-55.

[15] Omran, M. (2009). Post-privatization corporate governance and firm performance: The role of private ownership concentration, identity and board composition. Journal of Comparative Economics, 37 (4), 658-673.

[16] Agrawal, A., \& Knoeber, C. R. (1996). Firm Performance and Mechanisms to Control Agency Problems between Managers and Shareholders. The Journal of Financial and Quantitative
Analysis, 31 (3), 377.

[17] Al-Saidi, M., \& Al-Shammari, B. (2013). Board composition and bank performance in Kuwait: an empirical study. Managerial Auditing Journal, 28 (6), 472-494.

[18] Sheikh, N., Wang, Z., \& Khan, S. (2013). The impact of internal attributes of corporate governance on firm performance: Evidence from Pakistan. International Journal of Commerce and Management, 23 (1), 38-55.

[19] Muhammad, B., Hayat, Y., Iqbal, M. M., \& Khan, S. (2016). Perceived Effect of Shareholders on Corporate Governance (SSRN Scholarly Paper No. ID 2737853). Rochester, NY: Social Science Research Network.

[20] Dar, L., Naseem, M. A., Niazi, G. S. K., \& Rehman, R. U. (2011). Corporate governance and firm performance: A case study of Pakistan oil and gas companies listed in Karachi stock exchange. Global Journal of Management and Business Research, 11 (8).

[21] Butt, S. A., \& Hasan, A. (2009). Impact of ownership structure and corporate governance on capital structure of Pakistani listed companies. International Journal of Business \& Management, 4 (2).

[22] Hu, Y., \& Zhou, X. (2008). The performance effect of managerial ownership: Evidence from China. Journal of Banking \& Finance, 32 (10), 2099-2110.

[23] Rehman, R. ur, \& Mangla, I. U. (2012). Does Corporate Governance Influence Banking Performance? - ProQuest. Journal of Leadership, Accountability and Ethics 9.3, 86-92.

[24] Afgan, N., Gugler, K., \& Kunst, R. (2016). The effects of ownership concentration on performance of Pakistani listed companies. CBU International Conference Proceedings, 4 (0), 214-222.

[25] Cornett, M. M., Erhemjamts, O., \& Tehranian, H. (2015). Greed or Good Deeds: An Examination of the Relation between Corporate Social Responsibility and the Financial Performance of US Commercial Banks around the Financial Crisis. Available at SSRN 2333878.

[26] Hassan, R., Marimuthu, M., \& Johl, S. K. (2015). Diversity, Corporate Governance and Implication on Firm Financial Performance. Global Business and Management Research: An International Journal, 7, 28-36.

[27] Khatab, H., Masood, M., Zaman, K., Saleem, S., \& Saeed, B. (2011). Corporate governance and firm performance: A case study of Karachi stock market. International Journal of Trade, Economics and Finance, 2 (1), 39.

[28] Javed, M., Saeed, R., Lodhi, R. N., \& Malik, Q. U. Z. (2013). The effect of board size and structure on firm financial performance: A case of banking sector in Pakistan. Middle-East Journal of Scientific Research, 15 (2), 243-251.

[29] Javid, A. Y., \& Iqbal, R. (2010). Corporate governance in Pakistan: Corporate valuation, ownership and financing. Working Papers \& Research Reports, 2010.

[30] Butt, S. A., \& Hasan, A. (2009). Impact of ownership structure and corporate governance on capital structure of Pakistani listed companies. International Journal of Business \& Management, 4 (2).

[31] http://www.sbp.org.pk/departments/stats/FSA-2010-14.pdf 
[32] Dwivedi, N., \& Jain, A. K. (2005). Corporate Governance and Performance of Indian Firms: The Effect of Board Size and Ownership. Employee Responsibilities and Rights Journal, 17 (3), 161-172.

[33] Bokpin, G. A. (2013). Corporate disclosure, transparency and stock liquidity: Empirical estimation from the Ghana Stock Exchange. African Journal of Business Management, 7 (22), 2143.
[34] Nguyen, T., Locke, S., \& Reddy, K. (2014). A dynamic estimation of governance structures and financial performance for Singaporean companies. Economic Modelling, 40, 1-11.

[35] Sharma, N., \& Rathi, S. P. (2014). Corporate Governance: Conceptualization in Indian Context. 